\title{
Acute Liver Failure due to Hodgkin's Lymphoma
}

\author{
Eser Vardarelia Emine Dündar ${ }^{b}$ Vahap Aslan ${ }^{c}$ Zafer Gülbaş ${ }^{c}$ \\ Departments of a Gastroenterology, ${ }^{\mathrm{b}}$ Pathology and ${ }^{\mathrm{C} H e m a t o l o g y, ~ O s m a n g a z i ~ U n i v e r s i t y ~ M e d i c a l ~ F a c u l t y, ~}$ \\ Eskişehir, Turkey
}

\section{Key Words}

Hodgkin's disease · Liver failure · Liver biopsy

\begin{abstract}
Objective: To describe an unusual case of acute liver failure due to Hodgkin's lymphoma. Case Presentation and Intervention: A 37-year-old man was admitted with jaundice and abdominal distension. Physical examination showed tender hepatosplenomegaly, ascites, grade I encephalopathy, left cervical $(2 \times 1 \mathrm{~cm})$ and axillary $(1 \times$ $1 \mathrm{~cm}$ ) lymph nodes. The laboratory data revealed elevated serum bilirubin, transaminases, lactate dehydrogenase, and coagulation defects. Initially, primary liver disease was considered, but a liver biopsy revealed infiltration of the liver by Hodgkin's lymphoma that was confirmed by lymph node biopsy. Hodgkin's lymphoma was of lymphocyte depletion type. Conclusion: This case demonstrates that in the presence of lymphadenopathy involving acute liver failure, hematological malignancies should be taken into consideration. Liver and lymph node biopsies should be performed as early as possible. Copyright $@ 2004$ S. Karger AG, Basel
\end{abstract}

\section{Introduction}

Acute liver failure (ALF) can result from a wide variety of causes, of which viral and toxin-induced hepatitis are the most common $[1,2]$. ALF has also been reported in patients with malignant infiltration of the liver. Hematological malignancies are the most common underlying etiology, including Hodgkin's lymphoma (HL), non-Hodgkin's lymphoma, malignant histiocytosis, and leukemia [3-8]. However, it is distinctly uncommon for ALF to be the initial manifestation of a malignant process. An unusual case of HL presenting ALF is reported here.

\section{Case Report}

A 37-year-old male patient was admitted with jaundice and abdominal distension lasting for 5 days. The patient complained of weight loss, lack of appetite and nausea, which started 2 months ago. He did not use any medication. Two years ago, he had transfusion because of duodenal ulcer bleeding. On physical examination his body temperature was $38^{\circ} \mathrm{C}$, blood pressure was normal, scleras were icteric; hepatomegaly of $5 \mathrm{~cm}$, splenomegaly of $6 \mathrm{~cm}$, ascites and mobile lymph nodes in the left cervical region $(2 \times 1 \mathrm{~cm})$ and in the right axillary region $(1 \times 1 \mathrm{~cm})$ were found. Mental examination showed grade I encephalopathy.

Laboratory data were as follows: hemoglobin $10.2 \mathrm{~g} / \mathrm{dl}$, white blood cell count $2.8 \times 10^{9} / 1$, platelet count $10^{4} \times 10^{9} / 1$, erythrocyte sedimentation rate $48 \mathrm{~mm} / \mathrm{h}$, total bilirubin $300.96 \mu \mathrm{mol} / \mathrm{l}$, direct bilirubin $271.89 \mu \mathrm{mol} / \mathrm{l}$, alanine aminotransferase (AST) $356 \mathrm{IU} / \mathrm{l}$, aspartate aminotransferase (ALT) $168 \mathrm{IU} / 1, \delta$-glutamyl transpepti-

\begin{tabular}{ll}
\hline KARGER & ( ) 2004 S. Karger AG, Basel \\
Fax +4161306 1234 & 1011-7571/04/0136-0372\$21.00/0 \\
$\begin{array}{l}\text { E-Mail karger@karger.ch } \\
\text { www.karger.com }\end{array}$ & $\begin{array}{l}\text { Accessible online at: } \\
\text { www.karger.com/mpp }\end{array}$
\end{tabular}

Eser Vardareli, MD

Visnelik mah. Savas cad.

Abac1 apt. 63/21

TR-26020 Eskişehir (Turkey)

E-Mail eservardareli@yahoo.com 


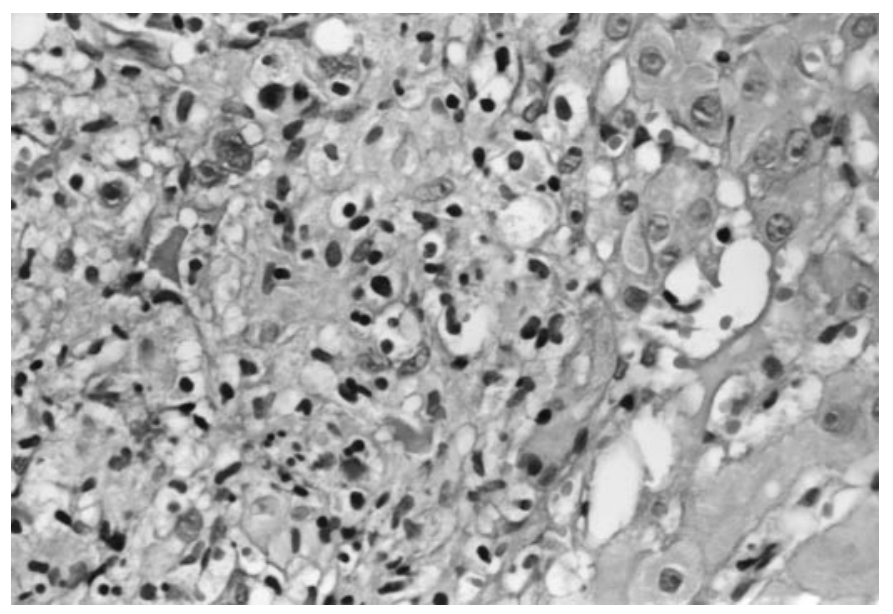

Fig. 1. Portal infiltrate by Hodgkin's and Reed-Sternberg cells in the context of spindle cells and lymphohistiocytic background in the liver. HE. $\times 400$.

dase 383 IU/l, alkaline phosphatase 2,310 IU/1, lactate dehydrogenase (LDH) 1,360 IU/l, total serum protein $4.6 \mathrm{~g} / \mathrm{dl}$, serum albumin $2.3 \mathrm{~g} / \mathrm{dl}$, prothrombin time (PT) $21 \mathrm{~s}$ (control: $14 \mathrm{~s}$ ), active partial thromboplastin time $35 \mathrm{~s}$ ( control: $28 \mathrm{~s}$ ), fibrinogen $2.4 \mathrm{mg} / 1$ and $\mathrm{C}$ reactive protein $0.8 \mathrm{mg} / \mathrm{l}$. Serologic tests for hepatitis A, B and C, toxoplasmosis, HIV, and EBV were negative. IgG, IgA, IgM, ceruloplasmin, ferritin, and $\alpha$-fetoprotein levels were within appropriate reference ranges. Antinuclear antibody was negative. Abdominal ultrasound revealed ascites, hyperechoic liver, and moderate hepatosplenomegaly without focal masses. The para-aortic region could not be investigated properly because of the ascites. The character of the ascitic fluid was that of a transudate. Brain CT showed mild cortical atrophy. Chest X-ray was normal. Blood, urine, and ascitic fluid were sterile on culture.

Ceftazidime (4 g/day) and amikacin ( $1 \mathrm{~g} /$ day) were given empirically for fever, but fever and jaundice did not improve. Ten days after hospitalization total bilirubin level increased to $571.14 \mu \mathrm{mol} / 1$ but ALT and AST levels regressed, PT was prolonged, and pancytopenia and grade III encephalopathy developed.

Needle liver biopsy was performed after fresh plasma transfusion because of coagulopathy. Histological examination of the liver showed portal based infiltration of atypical large mononuclear Hodgkin's cells with prominent eosinophilic nucleoli and typical ReedSternberg cells in the context of the haphazardly arranged spindle cells and capillaries with lymphohistiocytic background (fig. 1). In one area, infiltrate resembled hepatic granuloma due to the presence of epithelioid histiocytes. In addition, focal areas of coagulative necrosis were determined in hepatic parenchyma.

The left cervical lymph node biopsy which was performed after liver biopsy showed total loss of normal architecture and severe lymphocyte depletion with massive infiltration of typical and pleomorphic Reed-Sternberg cells and atypical large mononuclear Hodgkin's cells with a few mature lymphocytes (fig. 2). Atypical mitoses were frequently present. By immunohistochemical staining of formalinfixed paraffin-embedded tissue most of the Reed-Sternberg cells were immunoreactive for CD 30 (Nova Castra) (fig. 3). In addition, some of these cells were positive for CD 15 (Neo Markers), but negative for

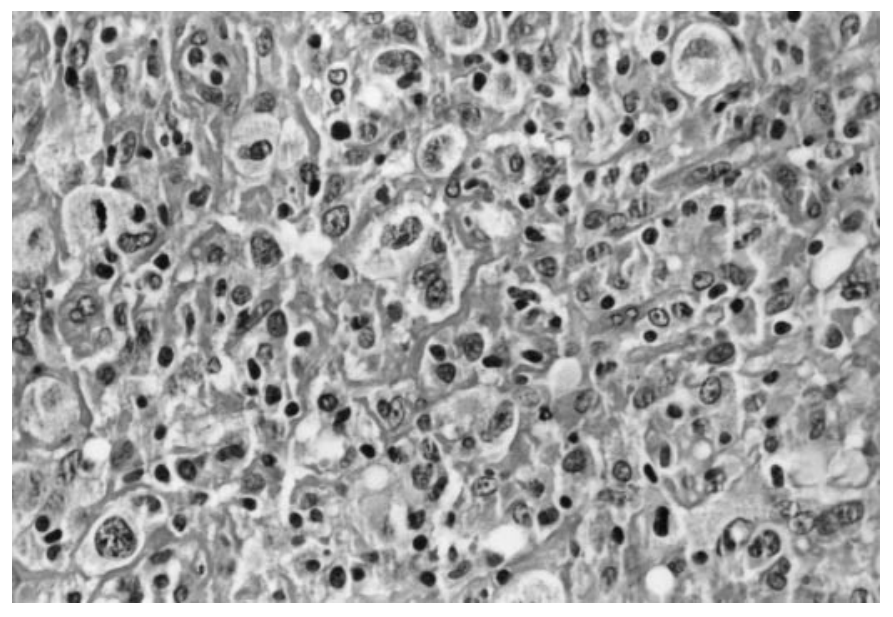

Fig. 2. Pleomorphic Reed-Sternberg cells are evident in virtually every high power microscopic field in lymph nodes. HE. $\times 400$.

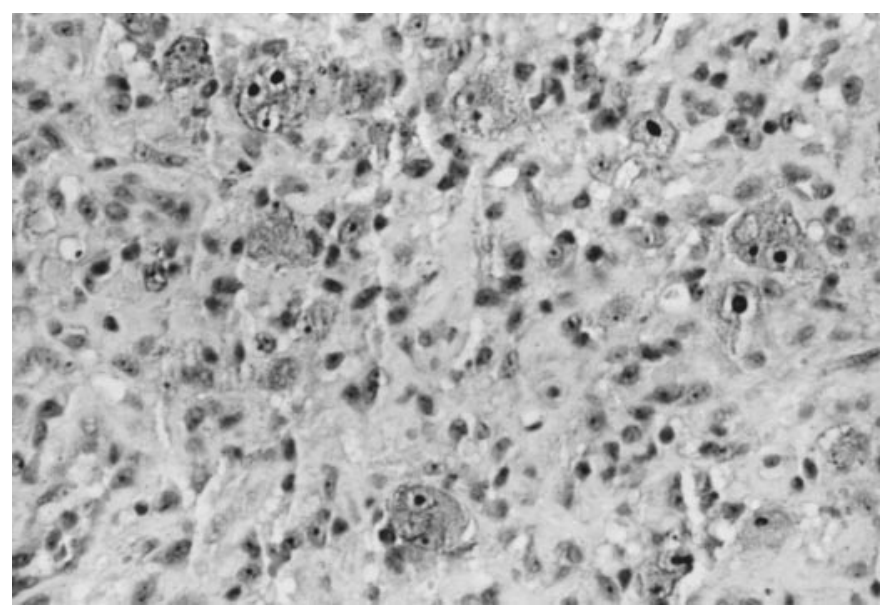

Fig. 3. CD 30 (Nova Castra) positivity in Reed-Sternberg cells in lymph node. CD $30 . \times 400$.

CD 20 (Neo Markers), CD 3 (Neo Markers) and CD 45 Ab-2 (Neo Markers). CD 3 positivity was determined in most of the background lymphocytic cell population. In addition to morphologic appearance, these immunohistochemical panel findings confirmed the diagnosis of reticular type of lymphocyte depletion HL. In the flow cytometric investigation of the cells obtained from such lymph nodes, clonal B cell increase could not be found.

After the diagnosis of HL, ABVD protocol (Adriamycin-bleomycin-vinblastine-dacarbazine) was given on the 12th day of hospitalization. During chemotherapy, hepatic encephalopathy improved, but after 2 days of chemotherapy, the patient's fever rose up to $39^{\circ} \mathrm{C}$, and tachycardia, tachypnea and hypotension developed. Ceftazidime was changed to imipenem, and teicoplanin was added. After 4 days of chemotherapy, the patient died of septicemia. Two days after his death, Staphylococcus aureus was obtained from the blood culture. 


\section{Discussion}

Most patients with lymphoma manifest their disease primarily in the lymphoid tissues and may have systemic symptoms and clinical or laboratory evidence of hepatic dysfunction [8]. Based on the findings of a percutaneous biopsy, peritoneoscopy, and laparotomy, liver involvement has been detected in $24 \%$ of patents with HL. However, cases associated with marked jaundice and hepatic failure are rare [9].

Making a diagnosis of hepatic infiltration in patients presenting with ALF in such cases is generally difficult and hence HL can be diagnosed late [5, 6]. However, early diagnosis is very important because it is possible that quick institution of specific chemotherapy may reverse the liver disease [5]. Clinical findings such as fever, malaise, abdominal pain, jaundice, ascites, hepatosplenomegaly, and laboratory findings indicating deranged liver function, coagulation defects, pancytopenia (all of them except abdominal pain were also seen in our patient) are not helpful for differential diagnosis [8]. All may be seen in a number of primary liver diseases. Ultrasonography and CT seem to be inadequate for the diagnosis of hepatic lymphoma [9]. As has been reported [4] in the presence of lymphadenopathy, enlarged liver and high LDH, lymphoma should be taken into consideration as an underlying cause. Although certain findings were present in our subject, our initial impression was that of decompensated chronic liver disease. Hence liver biopsy was performed at first to ascertain the etiology of ALF. However, the diagnosis of HL in a liver biopsy is difficult due to the small size of the specimen and scarcity of the diagnostic ReedSternberg cells or acceptable Reed-Sternberg variants.
Also the inflammatory changes are frequently nondiagnostic $[3,6,9]$. In our subject, Reed-Sternberg cells could be demonstrated by percutaneous liver biopsy after careful search in multiple sections. Lymph node biopsy revealed reticular subtype of lymphocyte depletion HL but previous reports indicate that liver diseases are mostly seen in mixed cellular and lymphocyte depletion subtypes of HL [10].

Several mechanisms have been reported to be involved in hepatic failure caused by lymphoma, including tumor infiltration of the biliary tree, hepatic vasculature, and hepatic parenchyma. Infiltration of small intrahepatic bile ducts may result in extensive cholangitis, duct necrosis, While tumor and ALF. Tumor obstruction of hepatic venules or tumor infiltration of sinusoids may result in hepatocyte ischemic injury and necrosis. Tumor infiltration of hepatic parenchyma may lead to a critical mass of hepatocyte destruction and subsequent ALF $[5,6,8,11]$. Hepatic failure can occur even if the infiltration of lymphoma cells in the liver is not substantial [12]. In our case, tumor cells had infiltrated extensively into the liver, and consequently hepatic failure and jaundice were considered due to massive liver involvement.

\section{Conclusion}

This case demonstrates that in the presence of lymphadenopathy and hepatomegaly in ALF patients hematological malignancies should be taken into account, and liver and lymph node biopsies should be performed as early as possible.

\section{References}

> O'Grady JG, Schalm SW, Williams R: Acute liver failure: Redefining the syndromes. Lancet 1993;342:273-275.

2 Sherlock S, Dooley J: Diseases of the Liver and Biliary System, ed 10. London, Blackwell Scientific, 1997, pp 103-117.

$\checkmark 3$ Chim CS, Choy C, Ooi CG, Liang R: Hodgkin's disease with primary manifestation in the liver. Leuk Lymphoma 2000;37:629-632.

$\checkmark 4$ Ghosh P, Fox IJ, Rader AM, Sorrell MF: Fulminant hepatic failure as the initial manifestation of non-Hodgkin's lymphoma. Am J Gastroenterol 1995;90:2207-2209.
15 Rowbotham D, Wendon J, Williams R: Acute liver failure secondary to hepatic infiltration: A single center experience of 18 cases. Gut 1998; 42:576-580.

6 Woolf GM, Petrovic LM, Rojter SE, Villamil FG, Makowka L, Podesta LG, Sher LS, Memsic L, Vierling JM: Acute liver failure due to lymphoma. Dig Dis Sci 1994;39:1351-1358.

$>7$ Colby TV, LaBrecque DR: Lymphoreticular malignancy presenting as fulminant hepatic disease. Am J Gastroenterol 1982;82:339-345.

$>8$ Suziki N, Tsuji H, Nakamura S, Asabe H, Sueishi K, Fujishima M: An autopsy case of Ki-1 lymphoma associated with hepatic failure. Am J Gastroenterol 1998;93:115-117.

$>9$ Dich NH, Goodman ZD, Klein MA: Hepatic involvement in Hodgkin's disease. Cancer 1989;64:2121-2126.
10 Mauch PM, Kalish LA, Kadin M, Coleman CN, Osteen R, Hellman S: Patterns of presentation of Hodgkin's disease: Implications for etiology and pathogenesis. Cancer 1993;71: 2062-2071

11 Zafrani ES, Leclercq B, Vernant JP, Pinaudeau Y, Chomette G, Dhumeaux D: Massive blastic infiltration of the liver: A cause of fulminant hepatic failure. Hepatology 1983;3:428-432.

12 Dourakis SP, Tzemanakis E, Deutsch M, Kafiri G, Hadziyannis SJ: Fulminant hepatic failure as a presenting paraneoplastic manifestation of Hodgkin's disease. Eur J Gastroenterol Hepatol 1999;11:1055-1058. 